\title{
KELOMPOK PETANI JAMUR TIRAM PUTIH DI DESA BLAYU, KECAMATAN WAJAK, KABUPATEN MALANG
}

\author{
Agus Sugianto ${ }^{1}$, Anis Sholihah ${ }^{2}$ \\ ${ }^{1}$ Fakultas Pertanian Universitas Islam Malang \\ Email : ags.unisma@yahoo.com \\ ${ }^{2}$ Fakultas Pertanian Universitas Islam Malang \\ Email : ash_unisma@yahoo.com
}

\begin{abstract}
Abstrak
Tujuan yang ingin dicapai dalam program ini adalah menghasilkan cacing tanah dan vermikompos sebagai wahana menciptakan lapangan pekerjaan tambahan dengan memanfaatkan limbah jamur tiram putih. IbM telah dilaksanakan di desa Blayu, kecamatan Wajak, kabupaten Malang, Jawa Timur, selama enam 8 bulan yaitu pada April - Nopember 2016. Metode yang digunakan dalam IbM ini adalah penyuluhan, pelatihan, demonstrasi, dan pendampingan. Hasil dari kegiatan Program Ipteks bagi Masyarakat ini dapat disimpulkan antara lain: 1). Petani jamur tiram puth yang tergabung pada kelompok tani Guyub Makmur I dan II telah menguasai teknologi metode budidaya cacing tanah, sutera dan vermikompos mencapai 85\%; 2). Telah tersedia sarana budidaya cacing tanah dan sutera dengan model Semi Closed Resirculating System (SCRS) guna untuk memanfaatkan limbah jamur tiram putih yang telah ada; 3). Capaian 100\% kelompok tani Guyub makmur I dan II telah dapat mengembangkan bibit cacing tanpa harus beli dari luar daerah; 3) Telah dihasilkan 2 buku ajar Teknologi Tepat Guna (TTG) yang akan diterbitkan oleh Aditya Media Publishing dengan ber-ISBN
\end{abstract}

Kata Kunci: Limbah Jamur, Cacing Tanah, Vermikompos, dan Cacing Sutera

\section{PENDAHULUAN}

Meningkatnya pengangguran pada usia produktif (19-55 th) memerlukan suatu solusi yang nyata untuk mengatasi hal tersebut. Peningkatan pengangguran tersebut telah memicu terhadap meningkatnya tindak kriminal seperti pencurian, perampokan dan lain sebagainya, disamping itu juga telah memicu terhadap generasi muda untuk segera pergi ke kota. Guna menekan kondisi tersebut pemeritah desa Blayu mengembangkan budidaya jamur kayu dengan harapan dapat meningkatkan perokonomian sekaligus menciptakan lapangan kerja baru bagi masyarakat, di samping itu mereka juga mengembangkan pertanian tanaman hortikultura pada lahan yang mereka miliki.

Kenyataan yang ada sekarang, petani yang telah mengembangkan budidaya jamur tiram putih tetapi selalu membuang limbahnya begitu saja. Mereka menganggap bahwa substrat sisa budidaya jamur tersebut sudah tidak bisa dimanfaatkan lagi. Secara teoritis substrat sisa budidaya jamur masih mengandung senyawa-senyawa organik seperti serat (lignin, selulosa, hemiselulosa, dan pektin), protein serta mineral. Artinya material 
ini masih bisa dimanfaatkan untuk membudidayakan cacing tanah (Sugianto, 2013).

Pemanfaatan cacing tanah secara ekonomis adalah sebagai berikut: 1). Bahan Pakan Ternak. Berkat kandungan protein, lemak dan mineralnya yang tinggi, cacing tanah dapat dimanfaatkan sebagai pakan ternak seperti unggas, ikan, udang dan kodok. 2). Bahan Baku Obat dan bahan ramuan untuk penyembuhan penyakit. Secara tradisional cacing tanah dipercaya dapat meredakan demam, menurunkan tekanan darah, menyembuhkan bronchitis, reumatik sendi, sakit gigi dan tipus. 3). Bahan Baku Kosmetik. Cacing dapat diolah untuk digunakan sebagai pelembab kulit dan bahan baku pembuatan lipstik. 4). Makanan Manusia. Cacing merupakan sumber protein yang berpotensi untuk dimasukkan sebagai bahan makanan manusia seperti halnya daging sapi atau Ayam.

Hitungan secara ekonomis berbudidaya cacing tanah selama empat bulan (120 hari) adalah Rp. 313.020.822,- dengan luasan tempat $200 \mathrm{M}^{2}$ dengan tingkat pengembalian modal selama dua bulan. Cacing tanah merupakan komoditas ekspor yang belakangan ini mendapat respon yang besar dari para petani ataupun pengusaha. Hal ini disebabkan karena besarnya permintaan pasar internasional dan masih kurangnya produksi cacing tanah. Budidaya cacing tanah dapat memberikan hasil yang besar dengan penanganan yang baik.

Masyarakat yang tergabung dalam kelompok petani jamur di dua dusun yaitu Krajan dan Sumbersuko, secara spesifik kelompok tersebut belum memiliki semangat yang luar biasa untuk mengembangkan usahanya di bidang budidaya cacing tanah. Pengetahuan dan teknologi budidaya cacing pernah dilakukan oleh beberapa anggota kelompok tani dengan cara mencoba-coba sehingga polanya keberhasilannya sulit dievaluasi.

Pola pengembangan manajemen dilakukan secara tradisional yang dapat dipilah menjadi tiga bagian yaitu pembelian bahan baku, pemrosesan substrat dan panen. Penanganan limbah belum terpikirkan. Limbah dibuang begitu saja di pekarangan atau kebun-kebun. Segala yang berhubungan dengan keuangan, pencatatan keuntungan hampir tidak pernah dilakukan. Hal ini berdampak pada akses untuk peminjaman modal dari pihak perbankan tidak pernah disetujui, sehingga selama terbentuknya kelompok jamur tersebut semua modal berasal dari swadaya.

Tujuan yang ingin dicapai dalam program ini adalah menghasilkan cacing tanah dan vermikompos sebagai wahana menciptakan lapangan pekerjaan tambahan dengan memanfaatkan limbah jamur tiram putih. Tiga keuntungan yang dapat diperoleh oleh petani sekaligus adalah pertama dari budidaya jamur tiram putih dapat memanen badan buahnya, kedua dari limbahnya yang dimanfaatkan sebagai media budidaya cacing tanah dapat memanen cacingnya, dan yang ketiga kotoran cacing yang 
dibudidayakan berupa vermikompos yang dapat dipakai sendiri atau dijual sebagai pupuk organik. Berdasarkan hal tersebut dari aspek ekonomis jelas dapat menambah penghasilan keluarga dan secara ekosistem tidak ada limbah yang mencemari lingkungan karena semuanya termanfaatkan.

\section{SUMBER INSPIRASI}

Masyarakat yang tergabung dalam kelompok petani jamur tersebar di tiga dusun yaitu Krajan, Pijetan dan Sumbersuko. Secara spesifik kelompok tersebut belum memiliki semangat yang luar biasa untuk mengembangkan usahanya. Pola pengembangan manajemen dilakukan secara tradisional yang dapat dipilah menjadi tiga bagian yaitu pembelian bahan baku, pemrosesan substrat dan panen. Segala yang berhubungan dengan keuangan, pencatatan keuntungan hampir tidak pernah dilakukan. Hal ini berdampak pada akses untuk peminjaman modal dari pihak perbankan tidak pernah disetujui, sehingga selama terbentuknya kelompok jamur tersebut semua modal berasal dari swadaya.

Penentuan sumber inspirasi berasal dari permasalahan prioritas mitra pada dua kelompok tani yang berasal dari Krajan dan Sumber Suko yang telah disepakati bersama dan disampaikan oleh ketua kelompoknya masing-masing adalah: 1). Permasalahan penguasaan pengetahuan dan teknologi budidaya cacing tanah yang adaptif dengan memanfaatkan limbah dari budidaya jamur tiram putih sehingga mampu menghasilkan biomas (cacing tanah itu sendiri) dan vermikompos (bekas cacing) sehingga tidak lagi terdapat limbah jamur yang dibuang sembarangan. Di samping itu dengan penguasaan teknologi tersebut, kelompok tani jamur memiliki nilai tambah yang sangat signifikan yaitu dapat menjual cacing tanah dan verminkomposnya; 2 ). Masalah yang berikutnya adalah masalah pemasaran dan penguatan kelembagaan yang ada pada kelompok petani jamur di Blayu sehingga mampu mengispirasi bagi warga masyarakat yang lain. Berdasarkan fakta dengan modal Rp. 12.715.000,- dalam waktu empat bulan akan menghasilkan panen $1600 \mathrm{Kg}$ cacing tanah, harga perkilogram adalah Rp.210.000,-sehingga keuntungan bersih yang diperoleh adalah Rp. 336.000.000,-. Hal ini justru lebih besar dari hasil budidaya jamur tiram itu sendiri.

\section{METODE KEGIATAN}

Berdasarkan analisis situasi dan permasalahan-permasalahan yang dihadapi kelompok tani desa Blayu, ada beberapa solusi yang ditawarkan untuk mengatasi permasalahan yaitu :1). Melakukan penyuluhan dan pelatihan budidaya cacing tanah dari limbah jamur tiram putih dan pembuatan varmikompos yang layak jual; 2). Menyediakan kandang pelidung, kandang cacing tanah, dan bibit yang unggul sebagai tempat aktivitas kelompok tani dalam usaha membudidayakan cacing tanah dan pembuatan vermikompos; 3). Melakukan penyuluhan tentang sistem 
manajamen budidaya cacing tanah tertata mulai dari pengadaan bibit, penyediaan substrat, dan sampai pemasarannya; 4). Melakukan pendampingan dalam proses budidaya cacing tanah dan pembuatan vermikompos hingga pengemasan produk produk tersebut.

\section{KARYA UTAMA}

\section{A. Budidaya Cacing Tanah, Sutera dan Vermikompos Berbasis Limbah Jamur}

Pelatihan budidaya cacing tanah dan cacing sutera dengan menggunakan limbah jamur sebagai substratnya telah mampu meningkatkan pengetahuan dan keterampilan anggota kelompok tani Guyub Makmur I berjumlah 10 orang dan dari Guyub Makmur II berjumlah 7 orang. Target yang diinginkan telah tercapai karena panen pertama untuk cacing tanah dan sutera berhasil mencapai 3-4 kali lipat dari bibit yang dikembangkan semula(Gambar. 1).

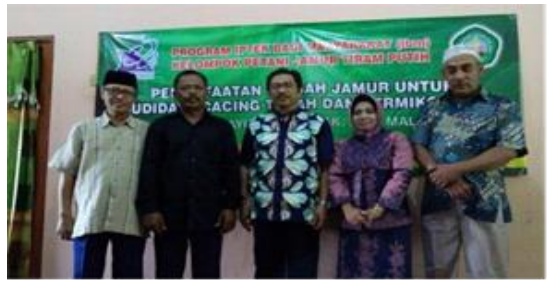

A. Pembukaan Pelatihan Oleh Kepala Desa Blayu

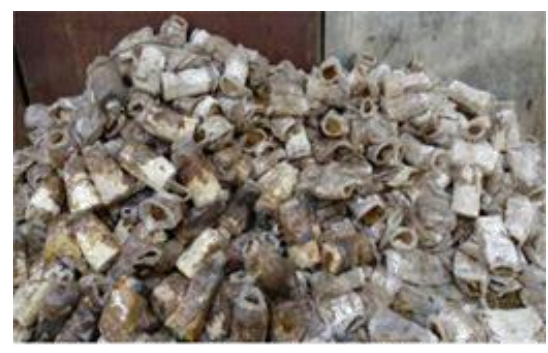

B. Limbah Jamur yang Belum Dimanfaatkan di Desa Blayu

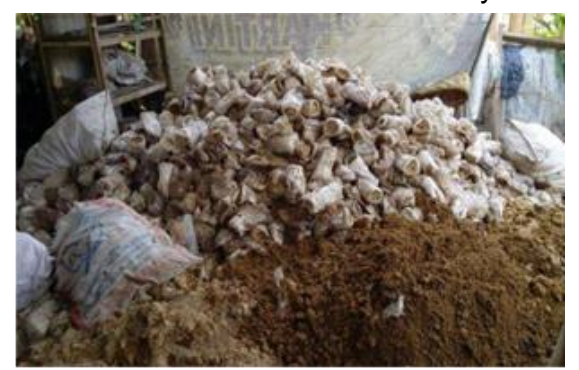

C. Pembuatan Media Untuk Cacing Tanah 


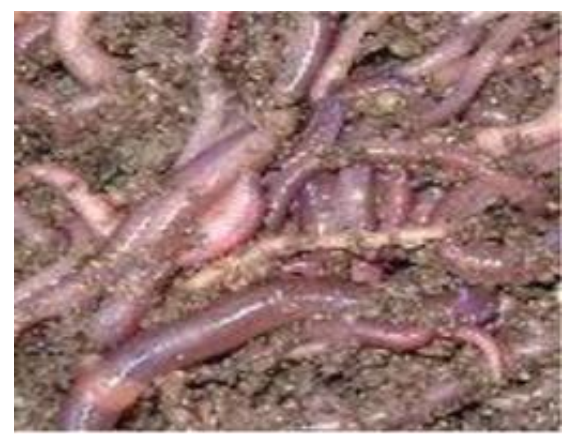

D. Bibit Cacing Tanah

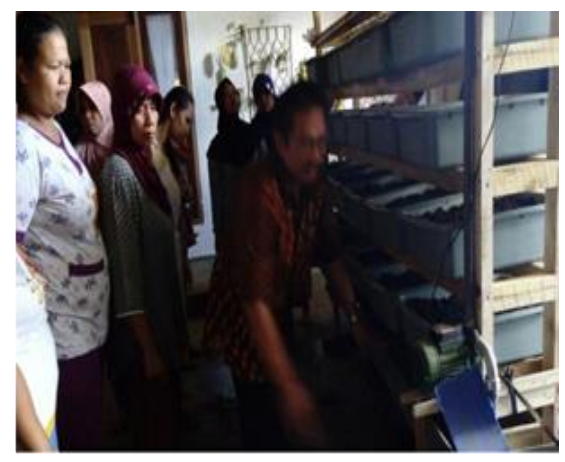

E. Model Budidaya Cacing Sutera Metode SCRS

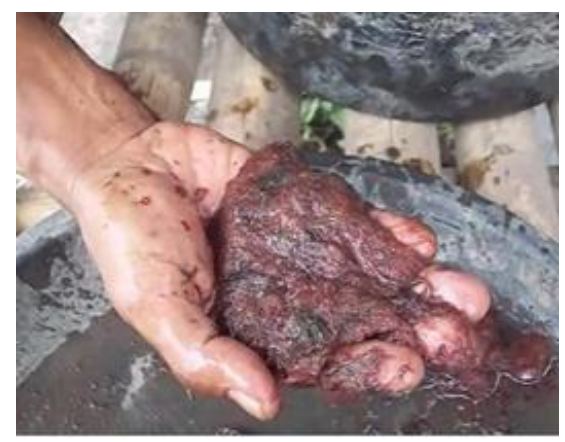

F. Bibit Cacing Sutera

\section{ULASAN KARYA}

Meningkatnya pengangguran pada usia produktif (19-55 th) memerlukan suatu solusi yang nyata untuk mengatasi hal tersebut. Peningkatan pengangguran tersebut telah memicu terhadap meningkatnya tindak kriminal seperti pencurian, perampokan dan lain sebagainya, disamping itu juga telah memicu terhadap generasi muda untuk segera pergi ke kota. Guna menekan kondisi tersebut pemeritah desa Blayu mengembangkan budidaya jamur kayu dengan harapan dapat meningkatkan perokonomian sekaligus menciptakan lapangan kerja baru 
bagi masyarakat. Sedangkan capaian target yang telah ditetapkan sebelumnya disajikan sebagai berikut:

Berdasarkan hasil evaluasi yang dilakukan pada tanggal 09 Nopember 2016, untuk panen pertama cacing tanah diperoleh bahwa dari 200 gram bibit tiap-tiap bak, telah tumbuh dan berkembang menjadi ratarata 800 gram. Artinya perkembangannya mencapai 4 kali lipat. Secara teoritis hal ini belum optimal karena cacing mampu tumbuh dan berkembang hingga mencapai 6 sampai 7 kali. Pada cacing sutera perkembangannya masih berkisar 3 kali lipat. Penyebab utamanya adalah bibit yang digunakan variasinya masih terlalu besar. Terutama untuk bibit cacing sutera masih diambil dari jenis liar yang berada di selokan-selokan.

Keberhasilan program IbM dapat terlihat dari rangkaian Gambar 5. Berikut:

A. Hasil Panen Pertama Cacing Tanah

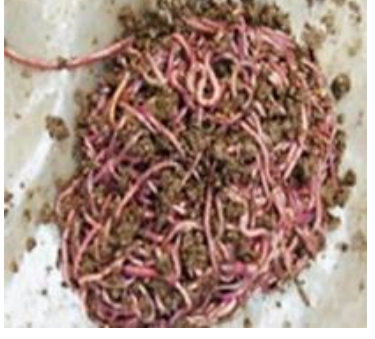

B. Pemilihan Bibit Cacing untuk

Dibudidayakan Berikutnya

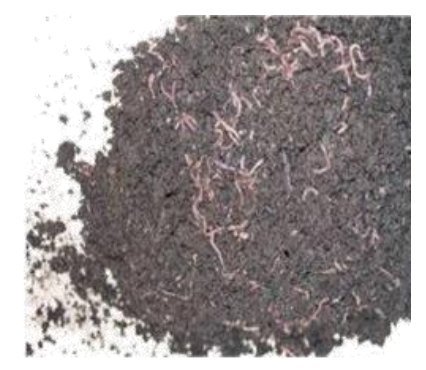

C. Vermikompos (Kascing) yang

Masih Bercampur dengan Cacing 


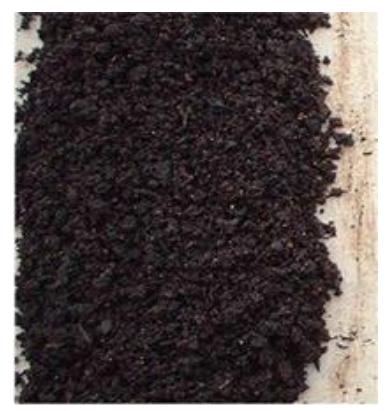

D. Vermikompos yang Sudah Dikeringkan
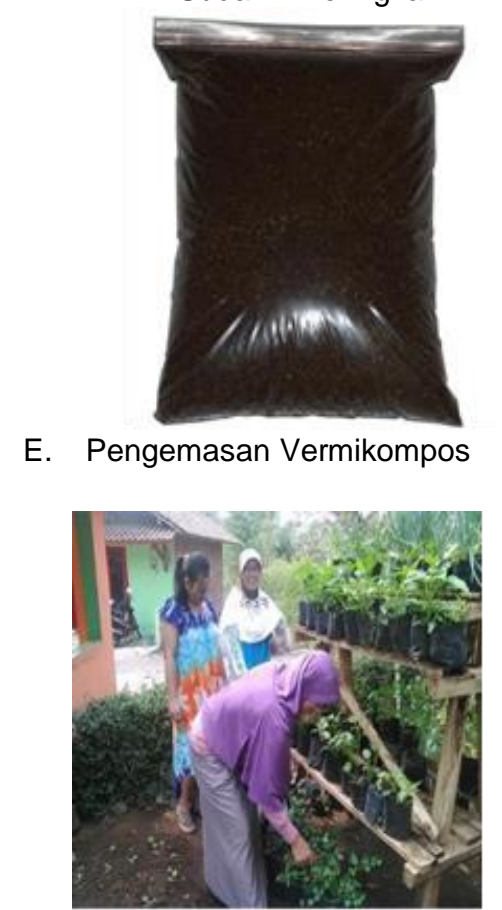

F. Aplikasi Vermikompos Pada Tanaman

\section{KESIMPULAN}

Kegiatan Program Ipteks bagi Masyarakat ini dapat disimpulkan antara lain:

1. Petani jamur tiram putih yang tergabung pada kelompok tani Guyub Makmur I dan II telah menguasai teknologi metode budidaya cacing tanah, sutera dan vermikompos mencapai $85 \%$

2. Telah tersedia sarana budidaya cacing tanah dan sutera dengan model Semi Closed Resirculating System (SCRS) guna untuk memanfaatkan limbah jamur tiram putih yang telah ada

3. Capaian $100 \%$ kelompok tani Guyub makmur I dan II telah dapat mengembangkan bibit cacing tanpa harus beli dari luar daerah 
4. Telah dihasilkan 2 buku ajar Teknologi Tepat Guna (TTG) yang akan diterbitkan oleh Aditya Media Publishing dengan ber-ISBN

\section{DAMPAK DAN MANFAAT KEGIATAN}

Dampak dan manfaat dari kegiatan IbM Kelompok Petani Jamur di desa Blayu, Wajak, kabupaten Malang adalah: 1). Limbah jamur yang selama ini dibuang telah dapat dimanfaatkan untuk budidaya cacing tanah dan sutera; 2). Akses penewaran modal masih dalam tahap penjajakan dan penewaran belum dilakukan survey dari perbankan; 3). Vermikompos yang dihasilkan dapat dimanfaatkan untuk tanaman hortikultura atau dikumpulkan untuk dijual; dan 4). Telah dihasilkan 2 buah buku ajar yang siap diterbitkan oleh Aditya Media Publishing dengan ber-ISBN.

\section{DAFTAR PUSTAKA}

Anonymous, 2012. Profil Desa Blayu, Kecamatan Wajak, Kabupaten

Malang, Laporan Kerja Tahunan Desa Blayu.

Sunawan dan A. Sugianto. 2005. Studi Pembibitan Dua Jenis Jamur

Kayu Lentinus edodes dan Pleurotus ostreatus Serta Pengujiannya Terhadap Berbagai Macam Campuran Nutrisi. J. Agritek. XIII : (4) 715-725

Sugianto, A. 2013. Teknologi TEL Jamur Tiram Putih untuk Melipat gandakan Produksi, Teknologi Hasil Fudamental Research 20102012. Aditya Media Publishing. Malang. 